\title{
OPEN Zinc(II) niflumato complex effects on MMP activity and gene expression in human endometrial cell lines
}

\author{
Miroslava Rabajdová ${ }^{1}$, Ivana Špaková ${ }^{1 凶}$, Zuzana Klepcová ${ }^{1}$, Lukáš Smolko $^{1}$, \\ Michaela Abrahamovská ${ }^{1}$, Peter Urdzík ${ }^{2} \&$ Mária Mareková $^{1}$
}

Endometriosis is a chronic inflammatory disease which increasingly affects young women under 35 years of age and leads to subfertility even infertility. Analysis of the cytotoxic effect of zinc(II) niflumato complex with neocuproine $\left(\left[\mathrm{Zn}(n e o)(n i f)_{2}\right]\right.$ or $\left.\mathrm{Zn}-\mathrm{Nif}\right)$ on immortalized human endometriotic cell line (12Z) and on control immortalized human endometrial stromal cell line (hTERT) was performed using xCELLigence technology for approximately $72 \mathrm{~h}$ following the treatment with $\mathrm{Zn}-\mathrm{Nif}$ as well as cell viability Trypan Blue Assay. $12 \mathrm{Z}$ cell line proliferated more slowly compared to unaffected cells, whereas hTERT cells did not show similar behavior after treatment. The complex probably reduces the effect of pro-inflammatory pathways due to the effect of NSAID, while presence of zinc might reduce the level of ROS and regulate ER2 levels and MMP activity. The observed effects and high selectivity for rapidly proliferating cells with increased inflammatory activity suggest a good prognosis of successful decrease of endometriosis stage with this complex.

Thickness of cylindrical endometrial epithelium changes cyclically due to the menstrual and ovarian cycles ${ }^{1}$ controlled by periodically produced gonadotropins $(\mathrm{GnRH})$ in the hypothalamus such as FSH (follicle stimulating hormone) and LH (luteinizing hormone) ${ }^{2}$. GnRHs are influenced by feedback levels of estrogens (mainly estradiol) and progesterones ${ }^{3}$. Endometriosis is defined as the presence of a endometrium-like tissue (glands, endometrial epithelial and stromal cells forming benign implants) in an area not typical for its occurrenceoutside the uterine cavity ${ }^{4}$ as a consequence of hormonal imbalance associated with immune deficiency and inflammatory processes ${ }^{5}$. Endometriosis tissue behaves similarly to a healthy endometrium, but is not excreted from the body by menstruation, decomposes, forms adhesions and is subject to develop vast inflammation ${ }^{6}$. It is often accompanied by pain in the pelvic floor, especially during the menstrual period, during and after sexual intercourse ${ }^{6}$ as scarring of the uterine cavity and the formation of adhesions occurs ${ }^{7}$. It also presents an increased risk of ovarian cyst formation (ovarian endometriosis), which causes reduced fertility and may even result in ovarian cancer ${ }^{8}$.

This chronic disease is a particularly common condition and occurs in up to $10 \%$ of women of childbearing age (presentation of the disease before the first period or after menopause is little known) ${ }^{9,10} .2-50 \%$ of affected women do not show the symptoms of disease (silent endometriosis), 40-60\% of women suffer from painful menstruation and $20-30 \%$ of women are unable to conceive (subfertile to infertile) ${ }^{6}$.

Unfortunately, the etiopathogenesis of the endometriosis remains unclear and there is no indisputable theory of its origin. The one of the most accepted cause of endometriosis implants is Sampson's theory of transplantation, in which viable endometrial epithelial and stromal cells, enters the peritoneal cavity through retrograde menstruation ${ }^{7}$, resulting in increased concentrations of iron accumulated in macrophages and mediates oxidative stress ${ }^{11}$.

Based on the localization, we can divide endometriotic tissues into three groups: (1) eutopic endometrium (endometrium in the uterine cavity); (2) ectopic endometrium (endometrium in ectopic cells in the peritoneum and abdominal cortes); (3) endometriosis lesions ${ }^{12,13}$. It distinguishes three forms of pelvic endometriosis: (1) peritoneal endometriosis, (2) ovarian endometriosis, (3) deeply infiltrated endometrial lesions ${ }^{7}$. Endometriosis rarely occurs extraperitoneally (as a result of deep infiltration) in the colon, kidneys, liver, pancreas or lungs ${ }^{7,14}$.

\footnotetext{
${ }^{1}$ Department of Medical and Clinical Biochemistry, Faculty of Medicine, Pavol Jozef Šafárik University, Trieda SNP 1, 04011 Košice, Slovakia. ${ }^{2}$ Department of Gynaecology and Obstetrics, Faculty of Medicine, Pavol Jozef Šafárik University, Košice, Slovakia. ${ }^{\circledR}$ email: ivana.spakova@upjs.sk
} 


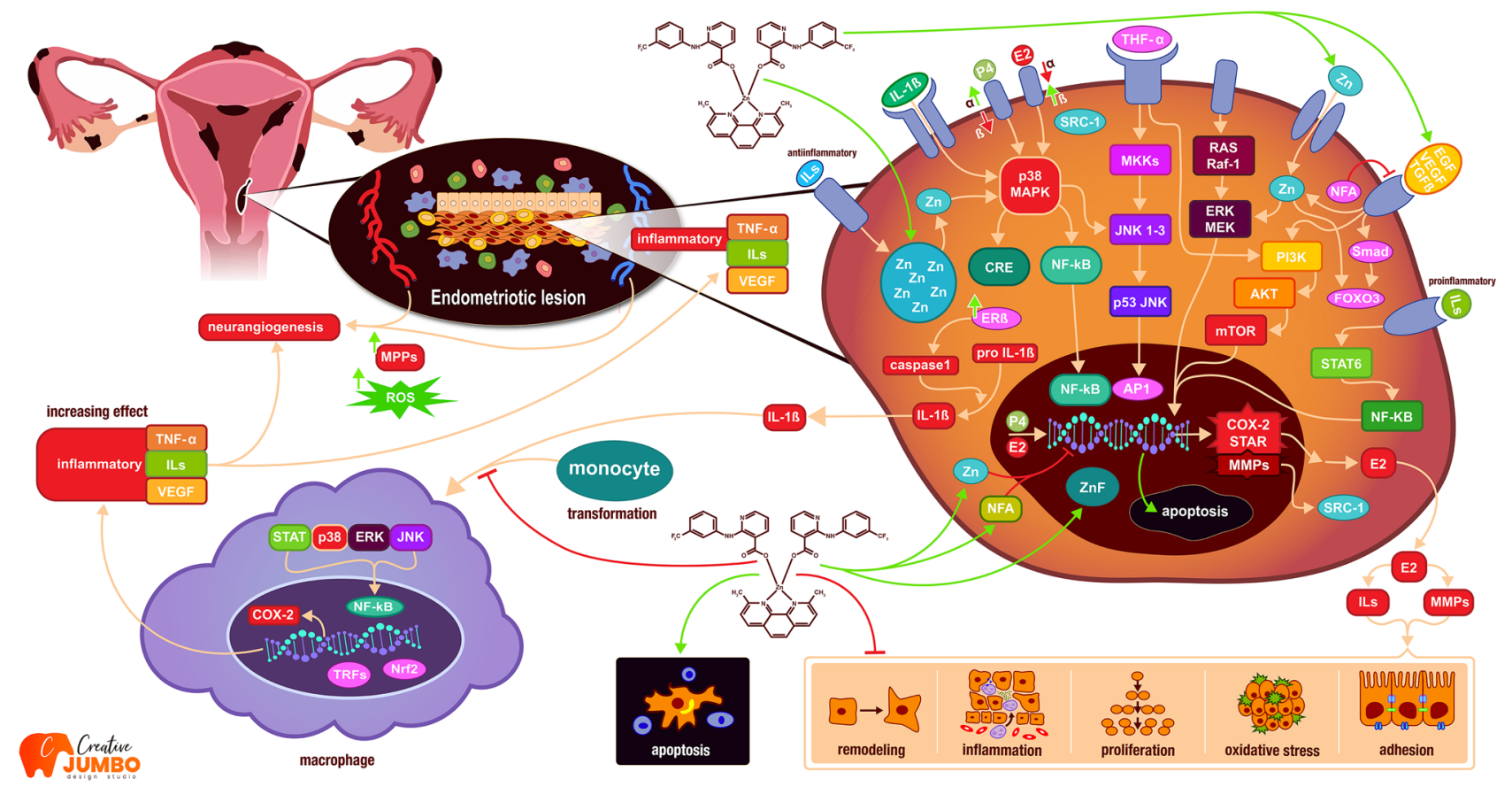

Figure 1. Mechanism of action of $\mathrm{Zn}-\mathrm{Nif}$ complex on endometriotic cells.

Biogenesis of endometriosis genitalis interna-endometriosis corpus uteri. Refluxed endometrial or endometrial-like cells in the peritoneal cavity attach to the underlying mesothelium, form an ectopic lesion, secrete chemokines, and stimulate immune cell infiltration through tumour necrosis factor alpha $(\mathrm{TNF} \alpha)^{15}$. Further through the feed-forward loop produces pro-inflammatory cytokines and prostaglandins, while anti-inflammatory interleukins are suppressed, resulting in an inflammatory imbalance ${ }^{16,17}$.

Endometriotic lesions form a unique microenvironment that is able to resist apoptotic stimuli, induce kinase activity, overexpress telomerase, and survivin which are physiologically actively expressed in the ovaries and endometrium ${ }^{18}$. Endometriotic cells are characterized by epigenetic modifications, chromosomal anomalies, instability, and mutations in a specific DNA sequence, leading to deregulation of the pathways involved in endometriosis ${ }^{7}$. During neuroangiogenesis vascular endothelial growth factor (VEGF) plays a key regulatory role ${ }^{17,19-21}$. Regulation of the mitogen activated protein kinase (MAPK) pathway via epidermal growth factor (EGF), protease-activated receptors (PAR), and tyrosine kinases directly involves these signalling pathways in the extra- and intracellular regulation of endometrial pathogenesis ${ }^{17}$. MAPK signalling also affects pain hypersensitivity by activating cyclooxygenase (COX) which is likely to lead to pelvic floor pain ${ }^{22}$. COX levels are closely related to the local production of estrogen (E2) and progesterone (P4) which in imbalance boost the expression of COX and pro-inflammatory agents 22,23 . The resulting stress conditions support the pathological protease activity of matrix metalloproteinases (MMPs) whose activity depends on P4 and on the level of zinc $(\mathrm{Zn})^{24}$. Endometriosis is responsible for subjective as well as objective changes (dysmenorrhea, dyspareunia, discretion, infertility, and irregular menstrual cycle) which together affect the patient's quality of life ${ }^{25}$. Influencing the activity of these kinases, proteinases, and hormone levels appears to be a potential target for treatment (Fig. 1).

MAPK pathway in endometriosis. The ability of the endometriotic microenvironment to support endometriotic cells is transmitted through kinase signalling pathways. Deregulation of protein kinase leads to uncontrolled cell proliferation, inflammation, increased leaching of neurodegenerative mediators and steroid hormones, iron deposition, and subsequent oxidative stress contribute to the development of endometriosis ${ }^{26}$.

Mitogen-activated protein kinases (MAPK, MAP2K, MAP3K) are a family of protein kinases that control cell division by ERK1-8 (extracellular signal-regulated kinase), mediate the immune response, differentiation, and cell survival via $\mathrm{p} 38 \alpha / \beta / \gamma / \delta$ and regulate transcription by the JNK1-3 system (c-jun-N terminal kinase) $)^{16,27}$. Protein kinases together with phosphatases catalyse the transfer of a phosphate group to the side chain of a serine, threonine, or tyrosine specific protein ${ }^{28}$. Phosphorylation controls enzyme activity, interactions between individual proteins and molecules, their localization within the cell, and degradation by proteases ${ }^{26}$. MAPK-directed phosphorylation of specific serine and threonine residues in the target protein (protein kinases, phospholipases, and transcription factors) regulates processes from gene expression, mitosis, metabolism to apoptosis ${ }^{17,29}$.

The ERK/MAPK signalling cascade is stimulated by, for example, growth factors, cytokines, viral infections or carcinogens ${ }^{30,31}$. Upon activation of ERK1/2, a number of transcription factors and serine/threonine kinases are activated that direct cells to differentiate and survive ${ }^{32}$. Increased phosphorylation of ERK, p38 and JNK in eutopic endometrial epithelial cells correlates with long-acting phosphorylation in ectopic epithelial cells of endometriotic lesions, which are activated mainly by increased activity of TNFa, IL-1 $\beta$ (which induce IL-6/8), 


\begin{tabular}{|l|l|l|l|l|l|l|l|}
\hline \multicolumn{7}{|l}{ Menstrual cycle phases } & \multicolumn{7}{l|}{ Menstrual } & \multicolumn{2}{l|}{ Proliferative } & \multicolumn{2}{l|}{ Secretory } \\
\hline \multirow{2}{*}{ Proteins } & Early & Late & Early & Late & \multicolumn{2}{l|}{ Early } & \multicolumn{2}{l|}{ Mid } & Late \\
\hline MMP-1 & ++++ & ++++ & + & + & + & + & + \\
\hline MMP-2 & +++ & +++ & ++ & ++ & ++ & ++ & ++ \\
\hline MMP-3 & ++++ & ++++ & + & + & + & + & + \\
\hline MMP-7 & ++++ & ++++ & ++++ & ++++ & + & + & + \\
\hline MMP-8 & ++++ & ++ & + & + & + & + & + \\
\hline MMP-9 & ++ & ++ & + & + & + & + & + \\
\hline MMP-10 & ++++ & ++++ & ++ & ++ & + & ++ & ++ \\
\hline MMP-11 & ++++ & ++++ & ++++ & ++++ & + & + & + \\
\hline MMP-12 & ++++ & + & + & + & + & + & + \\
\hline MMP-14 & +++ & +++ & ++ & ++ & ++ & ++ & ++ \\
\hline MMP-15 & ++ & ++ & ++ & ++ & ++ & ++ & ++ \\
\hline MMP-16 & + & + & ++ & ++ & ++ & + & + \\
\hline MMP-19 & ++ & ++ & ++ & ++ & ++ & ++ & ++ \\
\hline MMP-26 & + & + & ++ & ++ & ++++ & ++ & + \\
\hline
\end{tabular}

Table 1. Activity of MMPs during reproductive cycle of women; minimal activity: + , moderate activity: $++/+++$, strong activity: $++++{ }^{46}$.

COX-2, TGF $\beta$ (transforming growth factor $\beta$ ) via Raf, PGE2 (along with increased activity of VEGF, MCPI) and $\operatorname{ROS}\left(\mathrm{H}_{2} \mathrm{O}_{2}\right)^{16}$.

The increase in migratory ability and invasiveness of ectopic endometriosis tissue via the ERK/MAPK signalling pathway correlates with overexpression of the angiogenic inflammatory factor TGF- $\beta^{33}$. Cell migration is also supported by downregulation of cytokines that preserve vascular integrity and upregulation of MMPs (matrix metalloproteinases) ${ }^{34}$.

Dysregulation of the MAPK pathway in endometrial ectopic cells probably has a genetic basis and a positive family anamnesis is reported in $50 \%$ of patients $^{26}$.

The role of E2, P4 and MMP in inflammatory reactions due to COX-2 activation. Immune deficiency and persistent inflammatory environment stimulates immune system cells to non-physiological secretion of growth and angiogenic factors in endometriotic lesions ${ }^{35}$ promotes lesion implantation in the peritoneum, accelerates local inflammation, and grows in the ectopic endometrium ${ }^{36}$. The regulator of the immune system MIF (macrophage migration inhibitor factor) (in)directly affects endometrial tissue remodelling, proliferation, angiogenesis, and inflammatory responses ${ }^{37}$.

Pro-inflammatory and pathogenic stimuli at the transcriptional level (binding site in the COX gene promoter for NF- $\kappa \mathrm{B}$ - nuclear factor- $\kappa \mathrm{B}, \mathrm{CRE}$ - cAMP-responsive element, MIF, NF-IL-6-nuclear factor for interleukin-6, HIF-1 $\alpha$ (hypoxia-inducible factor $1 \alpha$ ) and translational level (CHX, heavy metals-Cd, eIF4E) ${ }^{38,39}$ induce ERK/ MAPK activation, resp. p38/MAPK pathways and COX enzyme formation (the COX-2 isoform is upregulated only in the presence of inflammation, COX-1 is constitutively expressed in tissues).

Prostaglandins (PGs) are prostanoids formed from arachidonic acid due cyclooxygenases action ${ }^{22}$, a family of lipoid hormones PGD2, PGE2, PGF2, and PGI2 that are involved in controlling reproduction (ovarian and menstrual cycle, fertility, and embryo implementation) and associated pathologies (menorrhea, dysmenorrhea, endometriosis) ${ }^{37}$. PGE2 in chronic inflammation induces inflammatory symptoms such as pain, edema, and phagocytosis ${ }^{40}$. PGE2 affects the stimulation of the angiogenic cytokine VEGF at the time of stromal implantation and decidualization, acts as a vasodilator, and thus promotes the growth of ectopic lesions ${ }^{41}$. MIF stimulates COX-2, thereby increasing the expression of PGE2 and key steroidogenic genes for local non-physiological overproduction of $17 \beta$-estradiol (E2) from cholesterol in endometriotic cells ${ }^{42}$.

PGE2-induced COX-2 activity is inhibited by E2 through p38/ERK/MAPK pathway signalling activity by binding to specific estrogen receptors $E R \alpha / \beta$ and affecting target genes ${ }^{23,43,44}$. PGE2 also regulates a number of metalloproteinases (MMPs-calcium-dependent zinc-containing endopeptidases), especially MMP-2/9, which are involved in the process of angiogenesis via intracellular MAPK pathways and VEGF ${ }^{22}$. MMPs are able to degrade collagen and elastin in the extracellular matrix and thus promote cell invasiveness ${ }^{45}$. In addition to estrogen, progesterone (P4), which affects transcription genes (e.g. Ihh, Ptch, Ekpb52), MMPs (MMP-2/9), cytokines (IL-6/8/1 $\beta, \mathrm{TNF} \alpha$ ) and decidualization markers (IGFBP-1, prolactin) ${ }^{24}$. In the menstrual cycle, the level of MMPs changes periodically depending on the phase of the cycle (see Table 1$)^{46}$.

Zinc and its role in endometriosis. Zinc (in ionized form of $\mathrm{Zn}(\mathrm{II})$ ) is an essential trace element which highly regulated homeostasis inhibits the effect of ROS, suppresses the activity of inflammatory cytokines, enzymes and adhesion molecules that lead to local inflammation ${ }^{47-49}$. Intracellular zinc signals act in an autocrine (mainly on liposomes, mitochondria and nucleus), paracrine and endocrine manner (zinc-secreting cells) ${ }^{50}$. Zinc activates MMPs that have a tumour suppressor effect and also inhibits the effect of ROS ${ }^{51}$. Oxidative stress 
in combination with zinc deficiency ${ }^{52}$ results in excessive activation of $\mathrm{MMPs}^{45}$ (since $\mathrm{Zn}$ (II) acts as inhibitor of MMPs and prevents substrate binding and degradation $)^{53}$ which leads to development of pro-inflammatory reactions $s^{54}$ that promote endometriotic lesion expansion and endometrial cell penetration occurs ${ }^{53,55}$.

Due to zinc extensive effect on inflammatory pathways, $\mathrm{Zn}$ (II) compounds possess great potential in treatment of inflammation and cancer.

Non-genomic signalling pathways of zinc ${ }^{50}$, in a zinc waves, mediate the cell response together with calcium influx, activation of the ERK/MAPK pathway through specific CK2 (casein kinase 2)-mediated phosphorylation, as well as PI3K and mTOR pathways, and ZIP7 channel phosphorylation ${ }^{48,49}$. These signalling pathways lead to genomic (transcriptional) responses, e.g. MTF-1 regulates target genes with the MRE region (transcription factors, developmental and cell cycle regulating genes) $)^{53,56,57}$, or by chromatin modification with $\mathrm{ZnF}$ (C2H2type Zinc finger proteins-transcription factors acting as tumour suppressors as well as oncogenes) ${ }^{58-60}$, or by regulating tumour cell migration and invasion ${ }^{60}$.

Non-steroidal anti-inflammatory drugs (NSAIDs) as potentially suitable ligands. Most nonsteroidal anti-inflammatory drugs (NSAIDs) are non-selective COX1-3 inhibitors ${ }^{61}$. The long-term use of NSAIDs has been shown to reduce the risk of cancer (breast, ovarian, prostate), induce apoptosis, inhibit proliferation, invasiveness, migration, and metastasis ${ }^{62-65}$.

The anti-inflammatory drugs also induce cell death through activation of $\mathrm{Bax}^{66,67}$, inhibition of prostaglandin $\mathrm{H}$-synthase (COX), further affect glucose metabolism, regulate tumour suppressor gene expression for PTEN, and MAPK phosphatase 3, as well as intracellular Calcium (antagonist to Zinc) ${ }^{68}$. Hence, NSAIDs as well as their metal complexes are currently also investigated as potential anticancer agents.

We focused our present study on a member of fenamate NSAIDs-niflumic acid ${ }^{63}$. Niflumic acid (NFA/ Hnif) is widely used in the treatment of painful menstruation ${ }^{62}$. The main role of NFA is induce changes in the intracellular level of Calcium ${ }^{69-73}$ the reduction of which leads to inactivation of the hyperosmotic induction of $\mathrm{COX}-2^{74,75}$. NFA at the concentration higher than that required for COX-2 inhibition leads to the accumulation of arachidonic acid, the increased concentration of which induces apoptosis by the involvement of caspase- 3 and alter mitochondrial permeability ${ }^{76}$. The apoptotic effect of niflumic acid is manifested by down-regulation of the ERK/MAPK cascade ${ }^{77}$, reduction of MMP-2/9 activity ${ }^{62}$, and increases the apoptotic effect ${ }^{78}$.

In an attempt to develop multi-target drug for treatment of endometriosis and related endometrial cancers and based on our previous studies of metal(II) niflumates we have designed and studied $\left[\mathrm{Zn}(\right.$ neo $\left.)(\text { nif })_{2}\right]$ complex which contains NSAID directly bonded to the zinc and might combine the positive effects of both components on endometriotic lesions.

\section{Material and methods}

Preparation and characterization of $\left[\mathrm{Zn}(\right.$ neo $\left.)(\text { nif })_{2}\right]$. Studied complex $\left[\mathrm{Zn}(\right.$ neo $\left.)(\text { nif })_{2}\right]$ was prepared in crystalline according to the previously reported procedure ${ }^{79}$. The structure of the complex was verified by single crystal X-ray diffraction analysis as well as spectral methods (IR, UV-VIS, fluorescence). The solution of the complex for the experiments with hTERT and $12 \mathrm{Z}$ cell lines was prepared by dissolving pure crystals of the complex in DMSO and subsequent dilution of the stock solution to the desired concentration by used medium (DMSO concentration in final solutions was $<0.5 \%$ ). Molecular structure model was created by using CCDC Mercury 2020.1 software.

Cell lines $12 \mathrm{Z}$ and hTERT. Human telomerase reverse transcriptase (hTERT) epithelial cells and 12Z endometriosis epithelial cells (ExPASy 12Z) were cultured in Dulbecco's Modified Eagle's Medium (DMEM) with $25 \mathrm{mM}$ glucose, $2 \mathrm{mM}$ glutamine, $10 \%$ Fetal Bovine Serum (FBS), $100 \mathrm{U} / \mathrm{ml}$ of penicillin, $0.1 \mathrm{mg} / \mathrm{ml} \mathrm{strep-}$ tomycin, and $1.25 \mathrm{~g} / \mathrm{ml}$ amphotericin in a thermoincubator at $37^{\circ} \mathrm{C}$ and $95 \% \mathrm{O}_{2}, 5 \% \mathrm{CO}_{2}$ atmosphere.

Cell culture $12 \mathrm{Z}$ was a gift from prof. Anna Starzinski-Powitz (Goethe-Universität Frankfurt), acquired in accordance with ethical rules. The hTERT cell line combines the in vivo properties of primary cells with the in vitro viability (ATCC hTERT).

xCELLigence assay. xCELLigence RTCA SP system (Roche Applied Science, Basel, Switzerland) measures changes in impedance (apparent resistance in terms of cell index) of built-in gold sensory microelectrodes at the bottom of E-plate 96 wells (ACEA Biosciences, Agilent, cat. no.: H029085). Measurements by xCELLigence assay on $12 \mathrm{Z}$ and hTERT cell lines were performed in biological triplicates, seeded at the density of 8000 cells/ well of $12 \mathrm{Z}$ and 20,000 cells/well of hTERT (based on previous optimization of ideal culture conditions measurements-cell concentration titration measurements). Background was measured at $100 \mu \mathrm{l}$ DMEM medium in an E-plate 96 in RTCA SP station (ACEA Biosciences) placed in the thermoincubator at $37^{\circ} \mathrm{C}$ and $95 \% \mathrm{O}_{2}, 5 \% \mathrm{CO}_{2}$ atmosphere. Subsequently, a suspension of $12 \mathrm{Z}$ cells and hTERT in a volume of $80 \mu \mathrm{l}$ per well was added. After about $24 \mathrm{~h}$ of incubation, another $20 \mu \mathrm{l}$ of DMEM medium with study substances was added to the medium with a final concentration of $100 \mu \mathrm{M} / 50 \mu \mathrm{M} / 10 \mu \mathrm{M} / 1 \mu \mathrm{M}$ for cis-platin (cisPt), niflumic acid, Zn complex, $\mathrm{ZnCl}_{2}$, neocuproine $(100 \mu \mathrm{M})$, and finally $0.5 \% \mathrm{DMSO}$. The Cell Index (CI-the impedance of gold electrodes in the bottom of the 96-well plate dependent from a cell adhesion) was measured for $94 \pm 2 \mathrm{~h}$ every $15 \mathrm{~min}$. Each experimental group was measured in triplicate. The slope interval was generated using RTCA software (ACEA Biosciences), which was used to evaluate the CI ratio. This methodology demonstrated the cytotoxic effect of the studied complex, whose CI was normalized to the same value at the normalization time point.

Cell viability: Trypan Blue Assay. The proliferative capacity and viability of $12 \mathrm{Z}$ and hTERT cell lines was detected using the Trypan Blue Staining Assay. Cells were seeded at the density of 150000 per well in a 6-well 
plate and cultured for $72 \mathrm{~h}$. Cells were affected with the $10 \mu \mathrm{M}\left[\mathrm{Zn}(n e o)(\text { nif })_{2}\right]$ before starting cell proliferation measurements. The percentage of viable cells (at $24 \mathrm{~h}$ ) was calculated.

Gelatine zymography. The collected media supernatants of $12 \mathrm{Z}$ and hTERT cells were mixed with sample buffer under non-reducing conditions. The samples were fractionated in $10 \%$ polyacrylamide gels containing $0.15 \%$ gelatine with electrophoresis running at constant $120 \mathrm{~V}$. After electrophoresis, the gels were washed with $2.5 \%$ Triton $\mathrm{X}-100$ for $2 \times 30 \mathrm{~min}$ in agitation and incubated in development buffer $(10 \mathrm{mM} \mathrm{CaCl}, 0.005 \mathrm{mM}$ $\mathrm{ZnCl}_{2}, 100 \mathrm{mM}$ Tris- $\mathrm{HCl} \mathrm{pH} \mathrm{7.4)} \mathrm{for} 48 \mathrm{~h}$ at $37^{\circ} \mathrm{C}$. After incubation, the gels were stained with $0.5 \%$ Coomassie Brilliant Blue R-250 in the solution of $40 \%$ isopropanol and $10 \%$ acetic acid for $1 \mathrm{~h}$ at room temperature and distained for $4 \mathrm{~h}$ in the solution of $40 \%$ methanol and $10 \%$ acetic acid, and for $20 \mathrm{~h}$ in the solution of $5 \%$ methanol, $10 \%$ acetic acid. Gelatinolytic activities were defined as white bands on a blue background. Proteolytic activity for pro-MMP-9, active-MMP-9, pro-MMP-2, and active MMP-2 in the gel was visualized at 92, 82, 72, and $62 \mathrm{kDa}$, respectively. The zymogram of each sample was run in duplicate.

Gene expression (q)RT-PCR. The total RNA was isolated with RNeasy Micro Kit (Qiagen, Hilden, Germany) from in the cool PBS harvested cells hTERT and $12 \mathrm{Z}$ (non-treated, treated with $10 \mu \mathrm{M}\left[\mathrm{Zn}(\right.$ neo $\left.)(\text { nif) })_{2}\right]$, and with $10 \mu \mathrm{M}$ cisPt for $24 \mathrm{~h}$ ). The sample concentration and purity was analysed by Nanodrop 2000c (Thermofisher Scientific, Waltham, MA, USA). The RNA samples were transcribed into cDNA by ProtoScript First Strand cDNA Synthesis Kit (New England BioLabs, Ipswich, MA, USA). The real-time PCR was provided using SensiMIX SYBR No-ROX (Bioline, London, UK) and forward/reverse primer of Gapdh (Invitrogen, Carlsbad, CA, USA), Mmp-2 (Invitrogen, Carlsbad, CA, USA), Mmp-9 (Invitrogen, Carlsbad, CA, USA) on Rotor Gene Q.

Spectral measurements of cell nuclei. The nuclei of unaffected cells as well as cells treated with $\left[\mathrm{Zn}(\right.$ neo $\left.)(\text { nif })_{2}\right](10 \mu \mathrm{M}$ concentration) were separated from the cell suspension by ultracentrifugation using standard sucrose density gradient method and lysed by dilution of the resulting suspension with distilled water (1:7). The simultaneous measurement of absorption and fluorescence spectra of the samples were performed on Horiba Dual-FL CCD spectrofluorometer at room temperature. The obtained data were analysed with Origin Pro 8 (v8.0891).

Statistical analysis. Cell index (CI) and normalized Cell Index (nCI) for real-time dynamic cytotoxicity assessment $(\mathrm{N}=3)$ and slope calculations for the migration assessments were calculated automatically by the RTCA Software of the RTCA system. Numerical data were expressed as a mean \pm standard deviation.

The final mRNA level of $M m p-2$, and $M m p-9$ were evaluated by comparative quantification and $\Delta \Delta \mathrm{Ct}$ values using the Rotor Gene Q Software (Qiagen, Hilden, Germany) and obtain the relative amount of target mRNA determined by the formula: target gene $1=2^{-\Delta \Delta \mathrm{Ct}}$ of target gene1.

Statistical differences between the means for the different groups were evaluated with GraphPad Prism 5.0 (GraphPad software, La Jolla, CA, USA) using the Multiple $t$ test with the level of significance and the One-way ANOVA with $p$ values: $p<0.05, p<0.01, p<0.001$ in analysis of cytotoxicity measurements.

\section{Results and discussion}

The recently reported complex $\left[\mathrm{Zn}(n e o)(n i f)_{2}\right]$ has shown promising potential in the preliminary cytotoxicity studies and thus it was selected for a more thorough investigation. Within the structure of the complex, central $\mathrm{Zn}(\mathrm{II})$ atoms are tetracoordinated by two oxygen atoms of niflumato ligands bonded in monodentate manner and two nitrogen atoms of chelate bonded neocuproine ligand (Fig. 2). Whereas the niflumato ligands are presumably the biologically most active part of the complex, the aromatic neocuproine ligand provides the additional stability and enhances its DNA as well as protein binding properties. The molecular structure of the complex resembles binding domains of $\mathrm{C} 2 \mathrm{H} 2$ coordinated $\mathrm{ZnF}$.

Our previous measurements of cytotoxicity interpreted as IC50 values show (Table 2) that the studied complex has approximately 4.6 -fold greater cytotoxic effect for rapidly proliferating $12 \mathrm{Z}$ cells compared to hTERT cells ${ }^{79}$. The cis-platin (cisPt) was selected as comparative compound to detect the efficiency of Zn-Nif complex.

Identification of acute and long-term response upon $\left[\mathrm{Zn}(\mathrm{neo})(\mathrm{nif})_{2}\right]$ treatment. We monitored the response profile of endometrial cell lines hTERT and $12 \mathrm{Z}$ at $\left[\mathrm{Zn}(\right.$ neo $\left.)(\text { nif })_{2}\right]$ at concentrations of 100, 50, 10 and $1 \mu \mathrm{M}$ using the xCELLigence Assay. Time-lapse data (approximately for $93 \mathrm{~h}$ ) describe in Fig. 3A the rapid and transient reduction in cell adhesion induced by the $100 \mu \mathrm{M}$ complex in both cell lines (hTERT and 12Z). The response of the cells to the $\mathrm{Zn}$-Nif at a concentration of 50 and $10 \mu \mathrm{M}$ had a long-term effect. $12 \mathrm{Z}$ cells responded after 24-30 h, whereas hTERT cells did not respond until 40-48 h.

Figure $3 \mathrm{~B}$ is a visualization of a short section before and after the studied $\mathrm{Zn}$-Nif. It is clear from the graph that the response of the cells of the endometriotic line $12 \mathrm{Z}$ to the added $\left[\mathrm{Zn}(n e o)(n i f)_{2}\right]$ is prompt and at the concentration of $100 \mu \mathrm{M}$ is fatal response. An initial increase in cell index (CI) was observed in $12 \mathrm{Z}$ cells which is thought to correspond to an increase in inflammatory pathways in the cells and a subsequent decrease in CI is followed by a gradual progression of cell death in the long-term phase after treatment with Zn-Nif at 50 and $10 \mu \mathrm{M}$. In contrast, we did not observe a similar increase in CI in hTERT cells immediately after the addition of the complex. The response of both cell lines to the $1 \mu \mathrm{M}$ concentration of $\mathrm{Zn}$-Nif correlated with the behaviour of the control unaffected cells. Figure $3 \mathrm{C}$ shows the $\mathrm{nCI}$ at the time of addition of $\left[\mathrm{Zn}(n e o)(\text { nif })_{2}\right]$. A direct reduction in adhesion of $12 \mathrm{Z}$ cells by $65-75 \%$ is visible compared to the hTERT cell line were no significant change in 


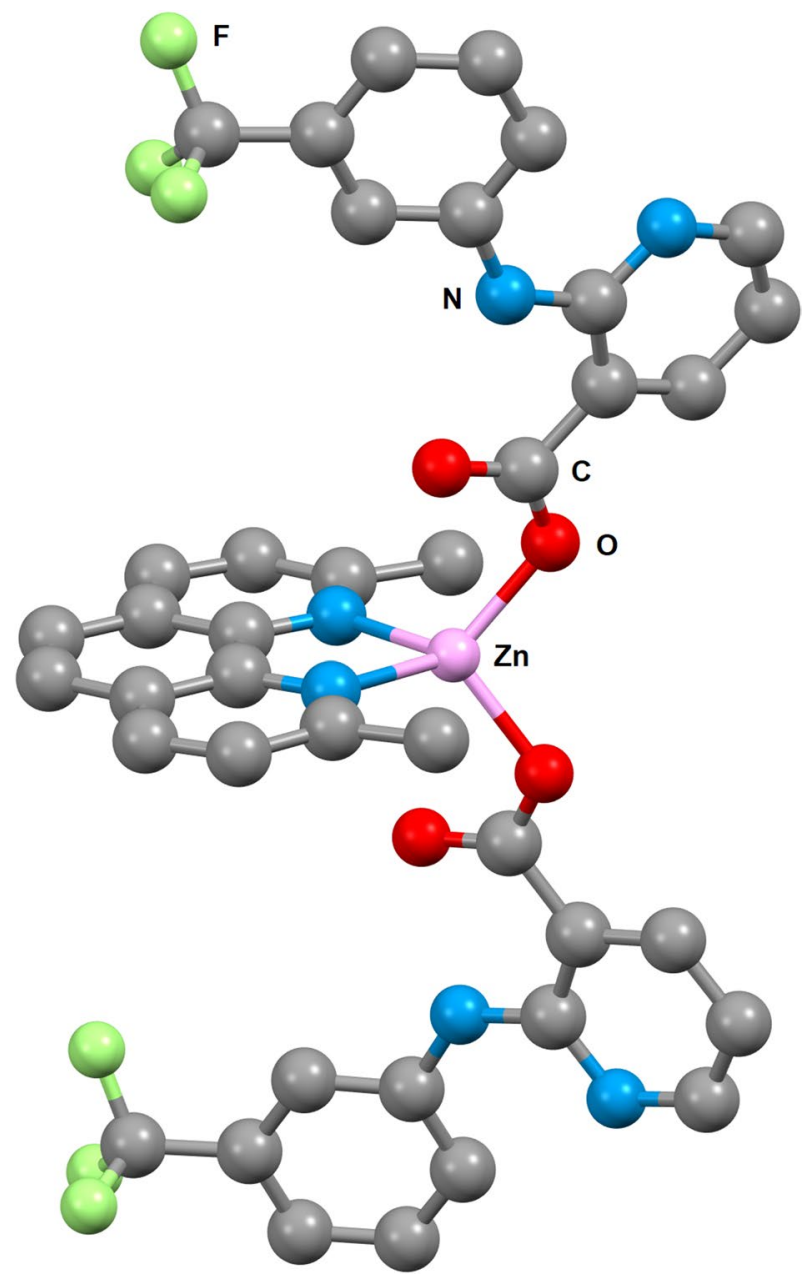

Figure 2. View of the molecular structure of studied complex $\left[\mathrm{Zn}(n e o)(n i f)_{2}\right]$. Hydrogen atoms were omitted for the sake of clarity (https://www.ccdc.cam.ac.uk/solutions/csd-core/components/mercury/).

\begin{tabular}{|l|l|l|}
\hline & IC $_{\mathbf{5 0}} \mathbf{1 2 Z}(\mathbf{m m o l} / \mathbf{l})$ & IC $_{\mathbf{5 0}}$ hTERT $(\mathrm{mmol} / \mathbf{l})$ \\
\hline cisPt & $>0.250(0.333)$ & $>0.250(1.181)$ \\
\hline$\left[\mathrm{Zn}(\right.$ neo $\left.)(\text { nif })_{2}\right]$ & 0.000895 & 0.00412 \\
\hline $\mathrm{MIX}\left(\mathrm{ZnCl}_{2}+\mathrm{H}\right.$ nif + neo $)$ & $>0.100(0.225)$ & $>0.100(0.899)$ \\
\hline
\end{tabular}

Table 2. $\mathrm{IC}_{50}$ calculated from $\mathrm{CI}$ at a time point $(72 \mathrm{~h})$ versus concentration 79 . The values of $\mathrm{IC} 5_{0}$ of the complex $\left(\left[\mathrm{Zn}(n e o)(n i f)_{2}\right]\right)$, cis-platin (cisPt), and the mixture of the complex components $\left(\mathrm{MIX}=\mathrm{ZnCl}_{2}+\mathrm{Hnif}+n e o\right)$. ${ }^{\star}$ Values in the brackets represent calculated $\mathrm{IC}_{50}$ values based on extrapolation.

impedance was observed within $15 \mathrm{~min}$ from the addition of complex to the cells (except for the concentration of $100 \mu \mathrm{M}$, where in both immediate lethal response was observed in the cell lines).

The $\mathrm{nCI}$ values depending on the concentration and time of action of the complex show that the concentration of $10 \mu \mathrm{M}$ has the expected cytotoxic effect on cells. This cytotoxic effect was more significant for cell line $12 \mathrm{Z}$ than for hTERT which is also indicated by Doubling time (in the total time of action of the Zn-Nif) for cell line $12 \mathrm{Z}$ has value $-28.5 \pm 2.3$ and for hTERT line has value $-141.8 \pm 20.9$. The slope (in the total time of action of the $\mathrm{Zn}-\mathrm{Nif}$ ) has value $-0.03 \pm 0.003$ for $12 \mathrm{Z}$ cells and $-0.003 \pm 0.0004$ for hTERT cells.

These data indicate that hTERT cells respond significantly more slowly and less destructively to the studied complex than rapidly proliferating $12 \mathrm{Z}$ cells. Apparently, the highest tested concentration of the complex $(100 \mu \mathrm{M})$ induces cell death in both lines after substance addition immediately. However, the complex concentration of 50 and $10 \mu \mathrm{M}$ leads to a long-term response in the form of a continuous decrease in CI with possibly an apoptotic end. On the other hand, this effect was not observed for the lowest tested concentration of $1 \mu \mathrm{M}$. The measured data using the xCELLigence Assay were also confirmed by another terminal method-Trypan Blue Assay. 
$12 Z$

A
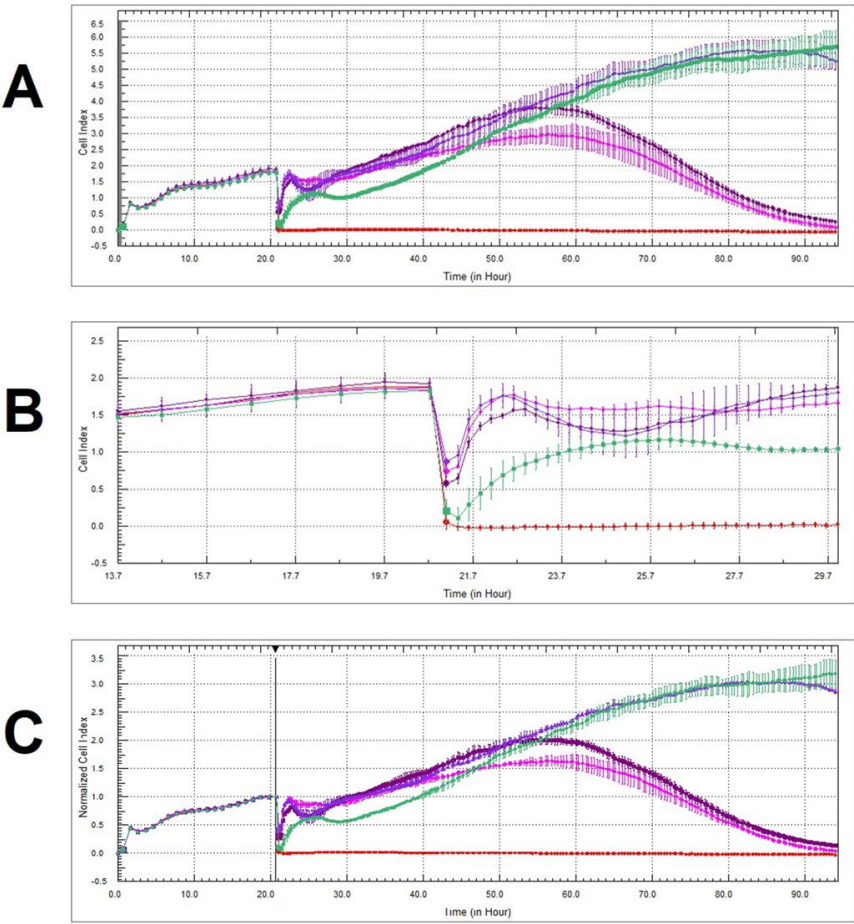

DMSO $0.5 \%$

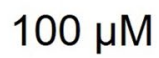

hTERT
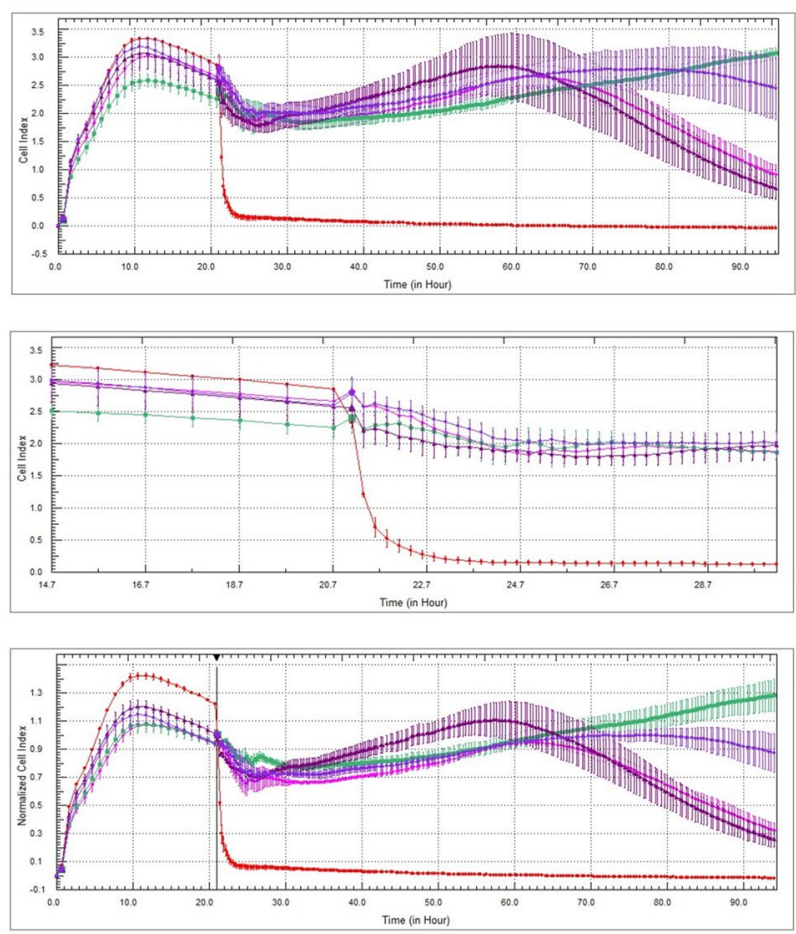

$50 \mu \mathrm{M}$

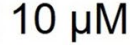

Figure 3. Cell Index (CI) and Normalized Cell Index (nCI) for $12 \mathrm{Z}$ and hTERT cells affected with [Zn(neo) $\left.(\text { nif })_{2}\right]$ (experimental cells) and 0.5\% DMSO (control cells). Data from xCELLigence RTCA SP system. (A) Cell Index raw data; (B) Detail of short time period prior to and following the addition of complex; (C) Normalized Cell Index raw data.

Cell adhesion (slope in the time interval 0-12 h) of affected cells with $10 \mu \mathrm{M}$ complex was for cells $12 \mathrm{Z} 4$-times lower than for hTERT cells. Proliferation of monitored cells (slope in the time interval $12-24 \mathrm{~h}$ ) of affected cells $12 \mathrm{Z} \mathrm{10-times} \mathrm{lower} \mathrm{than} \mathrm{in} \mathrm{control} \mathrm{cells.} \mathrm{Survival} \mathrm{of} \mathrm{affected} \mathrm{cells} \mathrm{(slope} \mathrm{in} \mathrm{the} \mathrm{time} \mathrm{interval} \mathrm{24-48} \mathrm{h)} \mathrm{for} 12 \mathrm{Z}$ 2-times higher than for hTERT. Cell death (slope in the time interval 48-72 h) for 12Z 5-times higher than for hTERT cells. The values of doubling time (Fig. 4) and slope values for adhesion, proliferation, survival, or cell death for individual time windows are in supplementary ST 1 (significance values in ST 2 and ST 3).

The inhibition of $12 \mathrm{Z}$ cell proliferation $12 \mathrm{~h}$ after treatment with $10 \mu \mathrm{M}$ was $87.64 \%$. Proliferation of hTERT cells $12 \mathrm{~h}$ after treatment with the complex $(10 \mu \mathrm{M})$ was unaffected and represented $116.25 \%$.

Effect of the $\left[\mathrm{Zn}(\right.$ neo $\left.)(\text { nif })_{2}\right]$ on cell nuclei. The potential effects of the complex on nuclei and possible interaction of the complex with nuclear genomic DNA were explored by absorption and fluorescence measurements. The comparison of the absorption spectra of the lysed cell nuclei samples from the unaffected cells and cells treated with $\left[\mathrm{Zn}(n e o)(n i f)_{2}\right](10 \mu \mathrm{M})$ for $24 \mathrm{~h}$ has revealed a visible decrease of the intensity of broad nucleoprotein absorption band in the samples isolated from the treated cells of both hTERT and $12 Z$ cell lines (Fig. 5). To evaluate observed differences between the samples, ratio between absorbance of samples from treated cells (A) and samples from unaffected cells (A0) at 260 and $280 \mathrm{~nm}$ wavelengths were calculated (Table 3). The absorbance at selected wavelengths correspond to the absorption of the nucleic acids $(260 \mathrm{~nm})$ and nuclear proteins $(280 \mathrm{~nm})$, respectively, and therefore can be used to determine the changes in the structure of these two nucleoprotein components. The hypochromic effect observed in samples from the cell treated with complex clearly indicate structural changes of the nucleic acids which are visibly more pronounced in case of $12 \mathrm{Z}$ cell line. Decrease in absorbance at $260 \mathrm{~nm}$ might be associated with both direct interaction of the complex with nucleic acids which was confirmed by our previous studies on isolated DNA samples ${ }^{79}$, as well as by affecting transcription factors ${ }^{80}$. Obtained results are also in line with the higher cytotoxicity of the complex against $12 \mathrm{Z}$ cell line which is reflected by more significant hypochromic effect of the absorbance in lysed cell nuclei sample isolated from the affected cells. In addition to the absorption measurements, a full excitation-emission matrix fluorescence measurements were carried out, however due to the similar position of fluorescence maxima of studied complex and nucleic acids it was not possible to confirm the presence of the complex within the isolated nuclei samples by this method. 

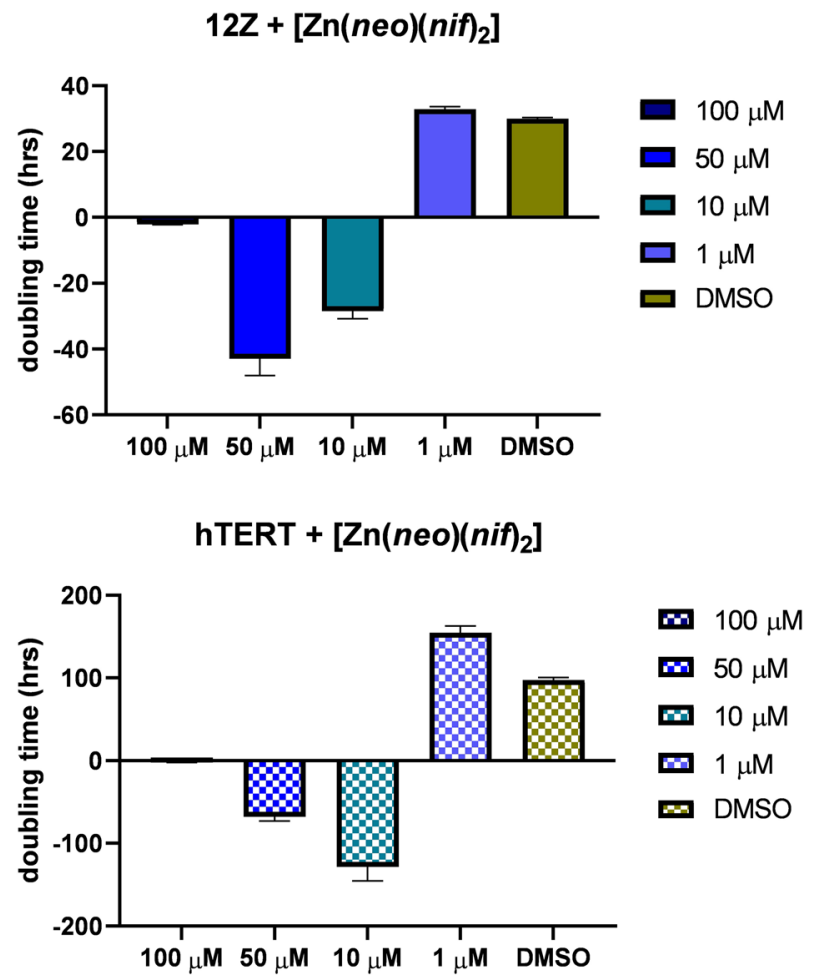

Figure 4. xCELLigence data for Doubling of $12 \mathrm{Z}$ and hTERT cells treated with $\left[\mathrm{Zn}(n e o)(n i f)_{2}\right]$ in different concentration.
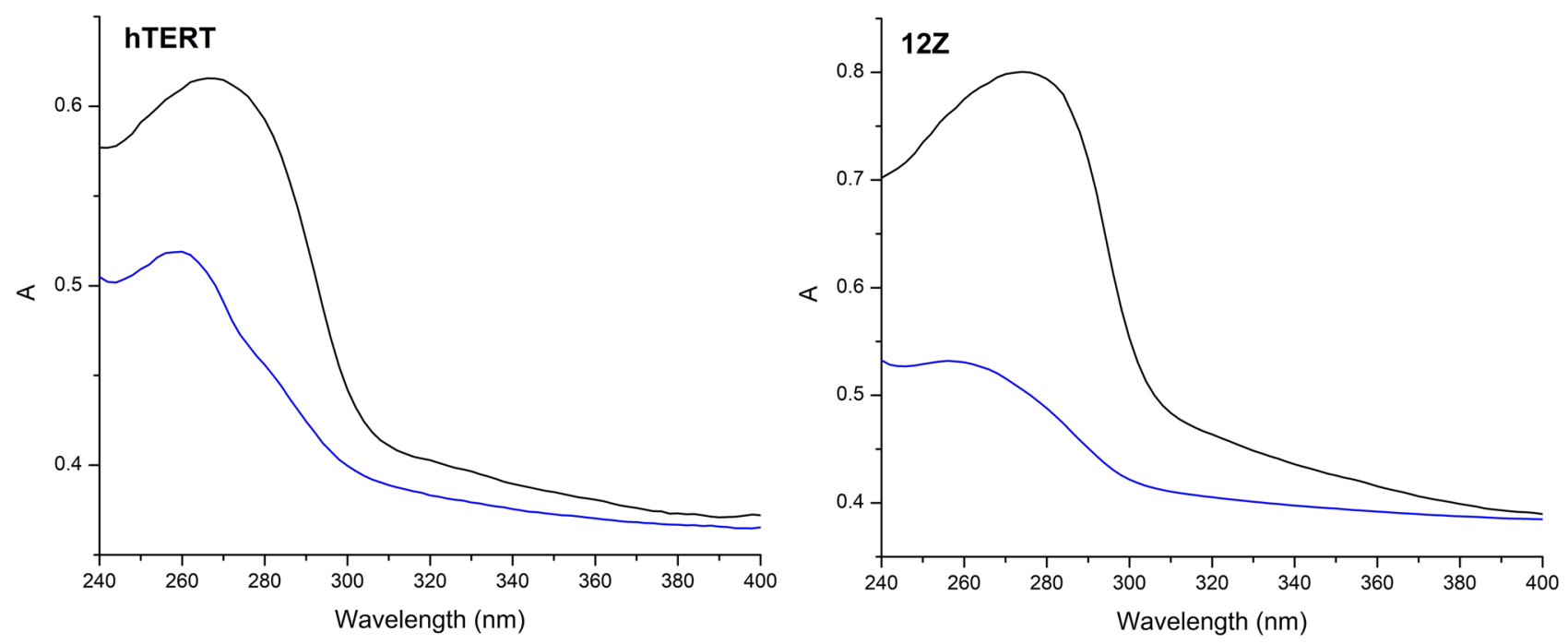

Figure 5. Absorption spectra of cell nuclei samples from unaffected cells (black) and cells treated with complex $(10 \mu \mathrm{M})$ for $24 \mathrm{~h}$ (blue) for hTERT (left) and $12 \mathrm{Z}$ (right) cell lines.

Effect of the $\left[\mathrm{Zn}(\right.$ neo $\left.)(\text { nif })_{2}\right]$ on the cell viability. Cell viability Trypan Blue test showed inhibition of cell proliferation for endometriotic cells $12 \mathrm{Z}$ and healthy control hTERT cells after $\left[\mathrm{Zn}(\right.$ neo $\left.)(\text { nif })_{2}\right]$ addition in concentration of $10 \mu \mathrm{M}$. Our present study identified Zn-Nif as possible effector of MAPK and COX-2 signalling, inhibition of which could induce apoptosis or apoptosis-like cell death.

We observed that $12 \mathrm{Z}$ cells affected by $\left[\mathrm{Zn}(\right.$ neo $\left.)(\text { nif })_{2}\right]$ had about $69 \%$ decrease of live cells at $48 \mathrm{~h}$ and hTERT cells which had about $29 \%$ decrease of live cells at $48 \mathrm{~h}$ (Fig. 6).

The cytotoxic, anti-proliferative, and inhibitory effect was significantly greater in endometriotic cell line $12 \mathrm{Z}$ than in the control endometrial cell line hTERT as already declared on the basis of the results obtained by the xCELLigence Assay and cell viability Trypan Blue Assay. The activity of the $\mathrm{Zn}$-Nif complex might be a result of its multi-target approach (anti-inflammatory, anti-cancer, pain suppression, activation of a tumour suppressor 


\begin{tabular}{|l|l|l|}
\hline Parameter & hTERT & $\mathbf{1 2 Z}$ \\
\hline $\mathrm{A}(260) / \mathrm{A}_{0}(260)$ & 0.851 & 0.685 \\
\hline $\mathrm{A}(280) / \mathrm{A}_{0}(280)$ & 0.769 & 0.615 \\
\hline $\mathrm{A}_{0}(260) / \mathrm{A}_{0}(280)$ & 1.03 & 0.98 \\
\hline $\mathrm{A}(260) / \mathrm{A}(280)$ & 1.29 & 1.09 \\
\hline
\end{tabular}

Table 3. Selected parameters calculated from absorption spectra of cell nuclei samples from hTERT and $12 \mathrm{Z}$ cell lines ( $\mathrm{A} 0=$ absorbance of samples from unaffected cells; $\mathrm{A}=$ absorbance of samples from cells treated with complex).

\section{Cell viability}

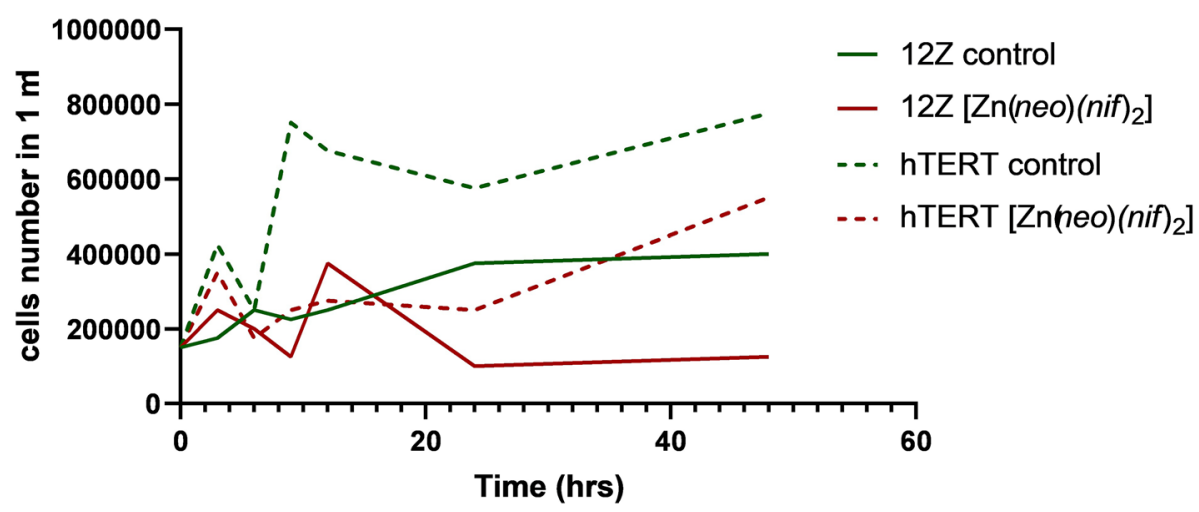

Figure 6. Cell viability of non-endometriotic hTERT cells and endometriotic $12 \mathrm{Z}$ cells with and without Zn-Nif complex.

MMPs, and inhibition of the ROS effect $)^{51,76,78}$. Based on results of xCELLigence RTCA analysis we have found that while the concentration of $1 \mu \mathrm{M} Z \mathrm{Zn}$-Nif has no cytotoxic effect in any interval of action on studied cell lines from, the concentration of $10 \mu \mathrm{M}$ has the desired cytotoxic effect on the treated $12 \mathrm{Z}$ cell culture but not on the treated hTERT cells after $24 \mathrm{~h}$. In our study, we observed that the $\mathrm{Zn}$-Nif inhibits proliferation, migration, and showed a selective cytotoxic effect which was manifested in a significant reduction of viable cells in $48 \mathrm{~h}$ by $69 \%$ in the $12 \mathrm{Z}$ cell line and by $29 \%$ in the hTERT cell line, respectively. These measurements show that hTERT cells are more resistant to the effect of $\left[\mathrm{Zn}(n e o)(n i f)_{2}\right]$ compared to $12 \mathrm{Z}$ cells and also correlate with the theory that NSAIDs complexed with bio-metal are more effectively reduce proliferation than NSAID alone ${ }^{79}$.

Effect of the $[\mathrm{Zn}($ neo)(nif) 2$]$ on the gene expression. A significant change in gene expression of $M m p-2$ and Mmp-9 (fold change to Gapdh) in the cells treated with $10 \mu \mathrm{M}\left[\left[\mathrm{Zn}(n e o)(\text { nif })_{2}\right]\right.$ was detected by RTPCR and qRT-PCR. Relative target gene expressions as fold change are shown in the Fig. 7.

The non-endometriotic hTERT cells showed significant increase of relative $M m p-2$ expression after $24 \mathrm{~h}$ incubation with $10 \mu \mathrm{M}\left[\mathrm{Zn}(n e o)(n i f)_{2}\right](p=0.0458)$ and $10 \mu \mathrm{M}$ cis Pt $(p=0.0005)$, and significant increase of relative $M m p-2$ expression after $24 \mathrm{~h}$ incubation with $10 \mu \mathrm{M}\left[\mathrm{Zn}(n e o)(n i f)_{2}\right](p=0.0002)$, and $10 \mu \mathrm{M}$ cis $\mathrm{Pt}(p=0.0004)$ in endometriotic $12 \mathrm{Z}$ cell line. In opposite, we analysed the significant decrease in hTERT of relative $M m p-9$ expression after $24 \mathrm{~h}$ incubation with $10 \mu \mathrm{M}\left[\mathrm{Zn}(\right.$ neo $\left.)(n i f)_{2}\right](p<0.0001)$ and $10 \mu \mathrm{M}$ cis Pt $(p<0.0001)$, and the decrease of relative $M m p-9$ expression after $24 \mathrm{~h}$ incubation with $10 \mu \mathrm{M}\left[\mathrm{Zn}(n e o)(n i f)_{2}\right](p<0.0001)$, and with $10 \mu \mathrm{M}$ cisPt $(p<0.0001)$ in $12 \mathrm{Z}$ cells.

Effect of the $[\mathrm{Zn}($ neo)(nif) 2 ] on active and latent form of MMPs. Following up on what was found by gene expression, we also performed the determination of MMP-2/9 by gelatin zymography as it is more sensitive than WB to these exopeptidases.

As shown by gelatine zymography (Fig. 8), treatment with cis Pt and Zn-Nif efficiently inactivated the release of proMMP-9 (latent MMP-9) into the medium of 12Z and hTERT cells. Latent MMP-9 in hTERT cell line treated with $10 \mu \mathrm{M}\left[\mathrm{Zn}(\right.$ neo $\left.)(\text { nif })_{2}\right]$ dropped by $65 \%$, and treated with $10 \mu \mathrm{M}$ cisPt was vanished.

ProMMP- 9 in untreated $12 \mathrm{Z}$ cell line was increased twice compared to untreated hTERT cell line, $12 \mathrm{Z}$ cells treated with $10 \mu \mathrm{M}\left[\mathrm{Zn}(\right.$ neo $\left.)(\text { nif })_{2}\right]$ decreased by $85 \%$ compared to untreated $12 \mathrm{Z}$ cells and $\pm 70 \%$ compared to untreated hTERT, and $12 \mathrm{Z}$ cells treated with $10 \mu \mathrm{M}$ cisPt decreased $80 \%$ compared to untreated $12 \mathrm{Z}$ and decreased $60 \%$ compared to untreated hTERT cells.

Latent MMP-2 in hTERT cell line treated with $10 \mu \mathrm{M}\left[\mathrm{Zn}(n e o)(n i f)_{2}\right]$ increased by $\pm 25 \%$ and treated with $10 \mu \mathrm{M}$ cisPt was decreased about $\pm 70 \%$. ProMMP- 2 in untreated $12 \mathrm{Z}$ cell line was decreased by $\pm 12 \%$ compared 

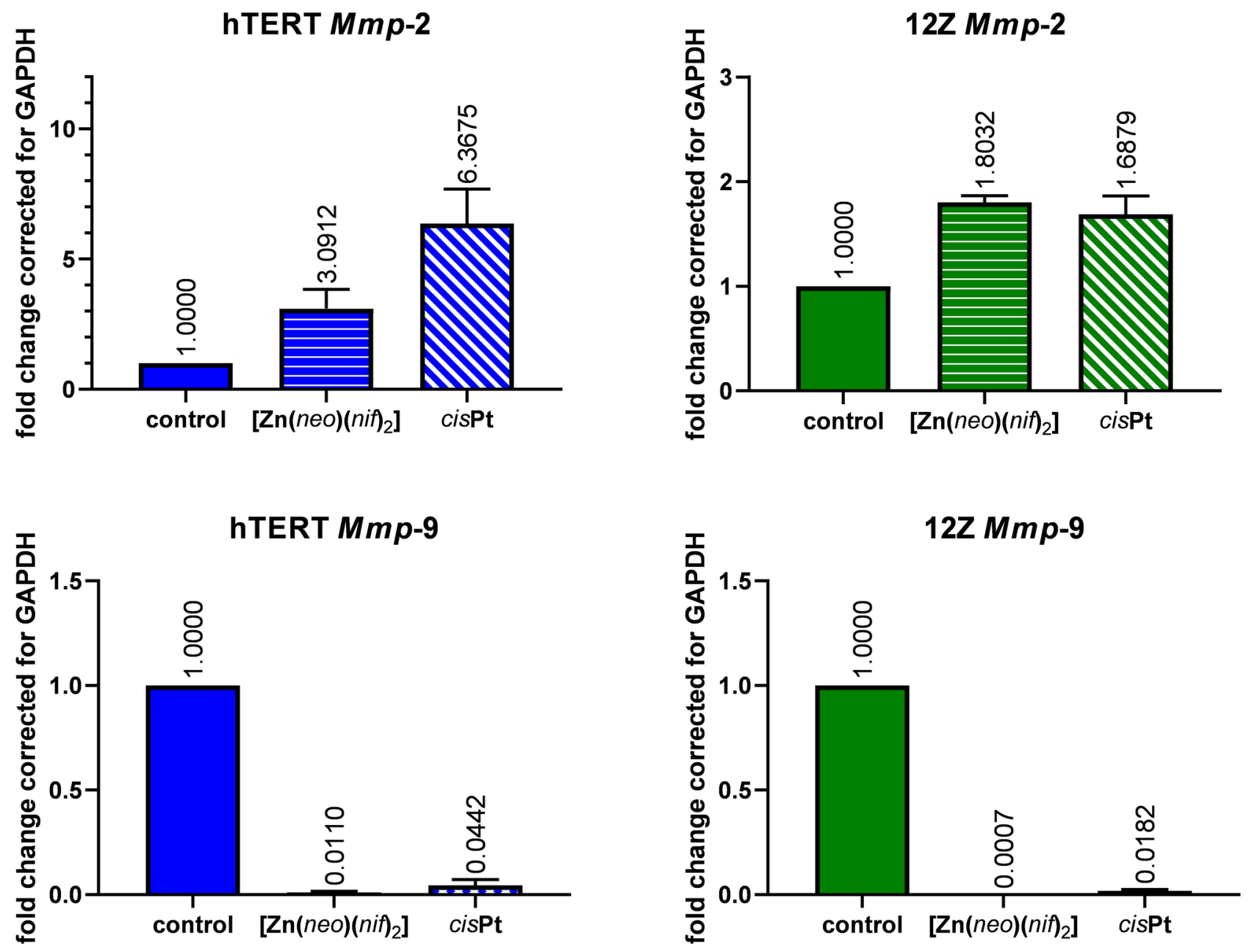

Figure 7. The relative gene expression of Mmp-2/9 in control (untreated cells hTERT or 12Z), cells treated with $10 \mu \mathrm{M}\left[\mathrm{Zn}(n e o)(\text { nif })_{2}\right]$ or $10 \mu \mathrm{M}$ cisPt for $24 \mathrm{~h}$.

to untreated hTERT cell line, $12 \mathrm{Z}$ cells treated with $10 \mu \mathrm{M}\left[\mathrm{Zn}(\right.$ neo $\left.)(\text { nif })_{2}\right]$ increased by $\pm 25 \%$ compared to untreated $12 \mathrm{Z}$ cells, and $\pm 30 \%$ compared to untreated hTERT. Experimental group of $12 \mathrm{Z}$ cells treated with $10 \mu \mathrm{M}$ cisPt decreased $\pm 40 \%$ compared to untreated $12 \mathrm{Z}$ and $\pm 32 \%$ compared to untreated hTERT cells.

We hypothesize that this mechanism of action is induced by the regulation of responses to the pro-inflammatory agents MAPK pathways (ERK, p38 and JNK) in eutopic epithelial cells of endometriotic lesions. The effect of $\left[\mathrm{Zn}(\right.$ neo $\left.)(n i f)_{2}\right]$ is on the transcriptional level in probably increased activity of TNFa, IL-1 $\beta$, TGF- $\beta$, VEGF, and other regulatory genes (e.g. Zn-dependent genes) in endometriosis and the same time affects the activity of MMPs ( $\mathrm{Zn}$ inactivates pathological activation of MMPs and promotes tumour suppressor activity of MMPs) $)^{51,74,78}$. Elevated level of MMP-2/9 may cause with ectopic endometriosis advanced progression or at its proliferative stage. The $\left[\mathrm{Zn}(\right.$ neo $\left.)(\text { nif })_{2}\right]$ effectively decreased MMP-9 which seems to have huge effect on proliferation of endometriotic cells. In opposite, we determined increased the MMP-2 protein levels after $\mathrm{Zn}$ (II) complex treatment (correlation with relative gene expression). The MMP-2 can have also protective function ${ }^{81}$ which seems to have an important role in our experiment and could explain the increased protein activity compared to decreased activity after cisPt treatment.

\section{Conclusions}

Our work demonstrates that the Zn-Nif is presumably affecting the activity of genes controlling the induction of apoptosis and may induce changes in the signalling mechanisms of inflammatory responses which can lead to cell cycle arrest. It is known that genes regulating inflammatory processes are influenced by the activity of zincfinger proteins, the role of which can probably be simulated by $\mathrm{Zn}$-complexes like $\left[\mathrm{Zn}(\right.$ neo $\left.)(\text { nif })_{2}\right]$. Therefore, we see great potential in further study of similar NSAID metal complexes.

Our results also suggest that XCELLigence assay could be a helpful tool for the future study of NSAID complexes with biometals and their application in the treatment of chronic inflammatory diseases such as endometriosis. Real-time analysis of the cytotoxic effect of experimental drugs is more appropriate than the end-point analysis in monitoring of the cells response to the studied substance and capturing significant metabolic changes ${ }^{82}$ and can contribute to finding the appropriate concentration of newly designed drugs such as $\left[\mathrm{Zn}(n e o)(\text { nif })_{2}\right]$. 
hTERT MMP-2

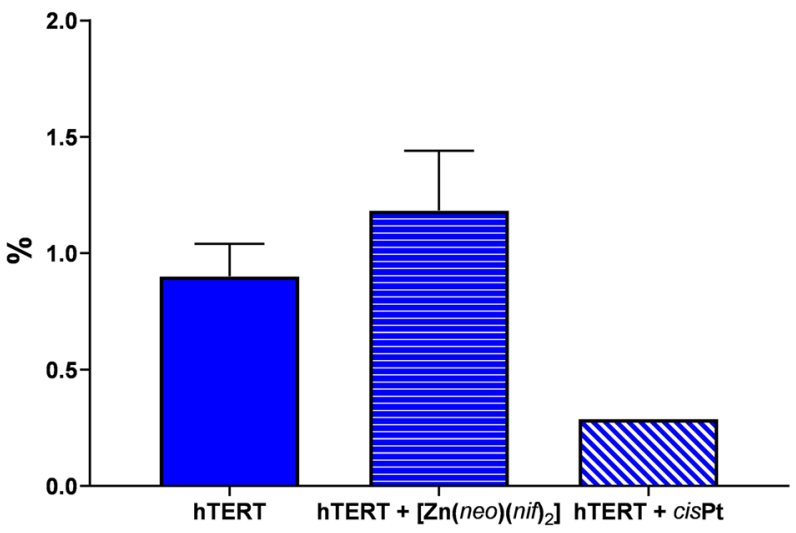

$12 Z$ MMP-2

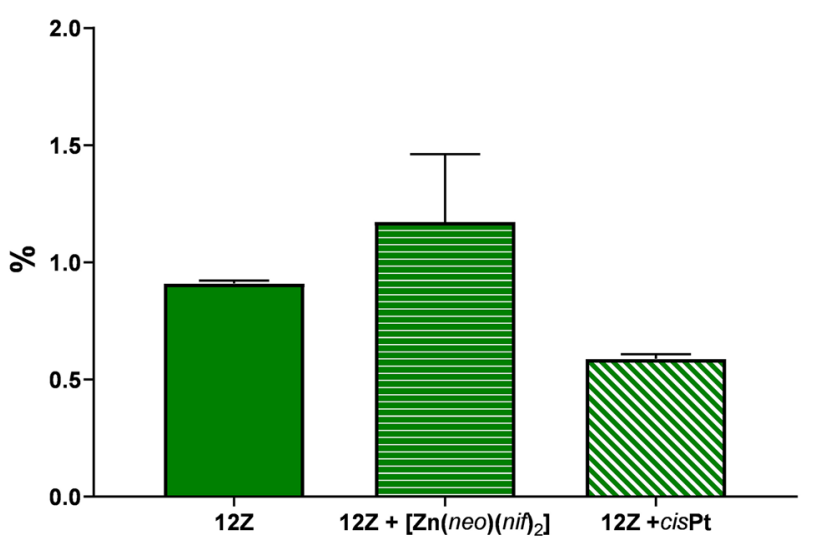

hTERT MMP-9

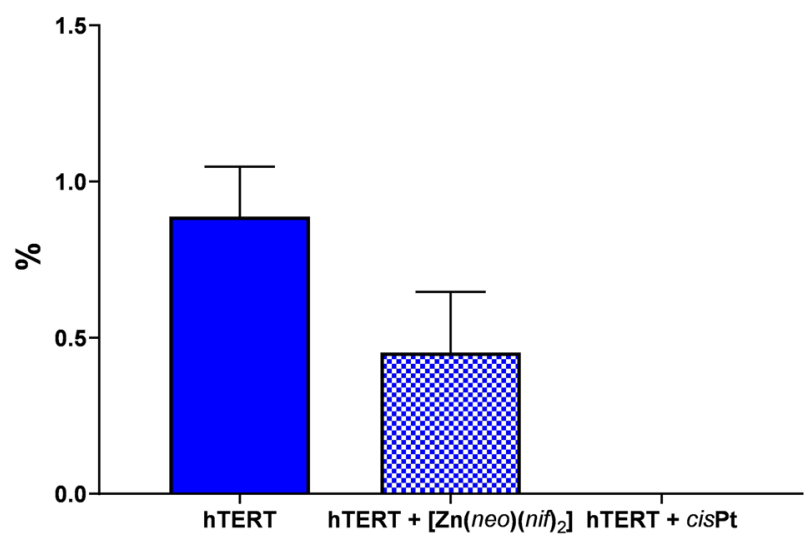

$12 Z$ MMP-9

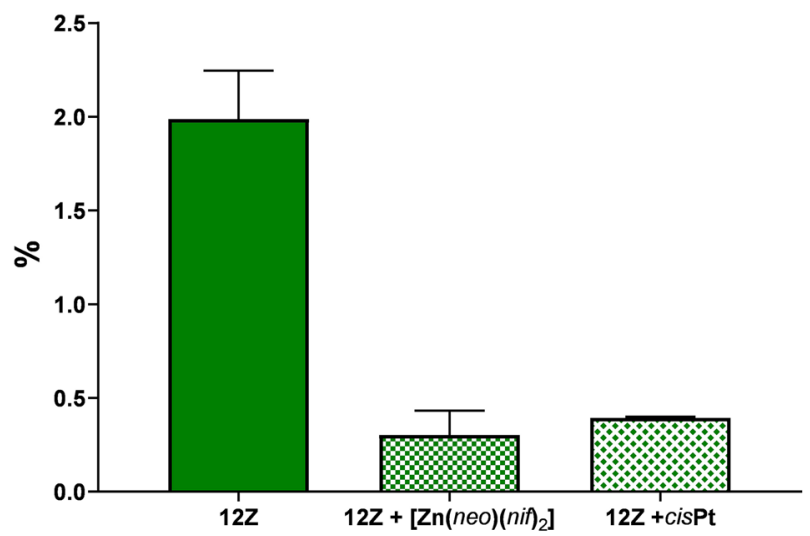

Figure 8. Total MMP-2/9 protein activity determined by gelatine Zymography in control (untreated cells hTERT or $12 \mathrm{Z})$, cells treated with $10 \mu \mathrm{M}\left[\mathrm{Zn}(\right.$ neo $\left.)(\text { nif })_{2}\right]$ or $10 \mu \mathrm{M}$ cisPt for $24 \mathrm{~h}$.

Received: 1 March 2021; Accepted: 8 September 2021

Published online: 27 September 2021

\section{References}

1. Krstic, R. V. Illustrated Encyclopedia of Human Histology (Springer, 2012).

2. Thiyagarajan, D. K., Basit, H. \& Jeanmonod, R. Physiology, Menstrual Cycle (St. Luke’s University, 2019).

3. Višňovský, J. Ovariálny a menštruačný cyklus (AlfaPrint, 2012).

4. Davila, G.W., Kapoor, D., Alderman, E., Hiraoka, M.K.Y., Ghoniem, G.M. \& Peskin, B.D. Endometriosis: Practice Essentials. Medscape, https://emedicine.medscape.com/article/271899-overview. Accessed 2018.

5. Paterni, I., Granchi, C., Katzenellenbogen, J. A. \& Minutolo, F. Estrogen receptors alpha (ER $\alpha)$ and beta (ER $\beta)$ : subtype-selective ligands and clinical potential. Steroids 90, 13-29 (2014).

6. Parasar, P., Ozcan, P. \& Terry, K. L. Endometriosis: epidemiology, diagnosis and clinical management. Curr. Obstet. Gynecol. Rep. 6, 34-41 (2017).

7. Klemmt, P. A. \& Starzinski-Powitz, A. Molecular and cellular pathogenesis of endometriosis. Curr. Womens Health Rev. 14, 108-116 (2018).

8. Vercellini, P., Viganò, P., Somigliana, E. \& Fedele, L. Endometriosis: pathogenesis and treatment. Nat. Rev. Endocrinol. 10, 261-275 (2014).

9. Liu, Z., Yi, L., Du, M., Gong, G. \& Zhu, Y. Overexpression of TGF- $\beta$ enhances the migration and invasive ability of ectopic endometrial cells via ERK/MAPK signaling pathway. Exp. Therap. Med. 17, 4457-4464 (2018).

10. Endometriosis fact sheet. https://www.acog.org/about_acog/news_room/ /media/newsroom/millionwomanmarchendometriosis factsheet.pdf. Accessed 2017.

11. Vitale, S. G. et al. The role of oxidative stress and membrane transport systems during endometriosis: a fresh look at a busy corner. Oxid. Med. Cell. Longev. https://doi.org/10.1155/2018/7924021 (2018).

12. Liu, H. \& Lang, J. H. Is abnormal eutopic endometrium the cause of endometriosis? The role of eutopic endometrium in pathogenesis of endometriosis. Med. Sci. Monit. 17, RA92-RA99 (2011).

13. Panir, K., Schhenken, J. E., Robertson, S. A. \& Louise Hull, M. Non-coding RNAs in endometriosis: a narrative review. Hum. Reprod. Update 24(4), 497-515 (2018).

14. Chamié, L. P., Ribeiro, D. M. F. R., Tiferes, D. A., Macedo Neto, A. C. \& Serafini, P. C. Atypical sites of deeply infiltrative endometriosis: clinical characteristics and imaging findings. Radiographics 38(1), 309-328 (2018).

15. Aznaurova, Y. B., Zhumatae, M. B., Roberts, T. K., Aliper, A. M. \& Zhavoronkov, A. A. Molecular aspects of development and regulation of endometriosis. Reprod. Biol. Endocrinol. 12, 50 (2014). 
16. McKinnon, B. D., Kocbek, V., Nirganakis, K., Bersinger, N. A. \& Mueller, M. D. Kinase signalling pathways in endometriosis: potential targets for non-hormonal therapeutics. Hum. Reprod. Update 22, 382-403 (2016).

17. Kyama, C. M. et al. Non-steroidal targets in the diagnosis and treatment of endometriosis. Curr. Med. Chem. 15, 1006-1017 (2008).

18. Mormile, R. \& Vittori, G. MAPK signalling pathway and endometriosis: what is the link?. Arch. Gynecol. Obstet. 287, 837-838 (2013).

19. Asante, A. \& Taylor, R. N. Endometriosis: the role of neuroangiogenesis. Annu. Rev. Physiol. 73, 163-182 (2011).

20. Sanfilippo, J. S., Williams, R. S., Yussman, M. A., Cook, C. L. \& Bissonnette, F. P. Substance P in peritoneal fluid. Am. J. Obstet. Gynecol. 166, 155-159 (1992).

21. McKinnon, B. D., Evers, J., Bersinger, N. A. \& Mueller, M. D. Induction of the neurokinin 1 receptor by TNFa in endometriotic tissue provides the potential for neurogenic control over endometriotic lesion growth. J. Clin. Endocrinol. Metab. 98, 2469-2477 (2013).

22. Lai, Z. Z. et al. Cyclooxygenase-2 in endometriosis. Int. J. Biol. Sci. 15, 2783-2797 (2019).

23. Kim, S., Campbell, J., Yoo, W., Taylor, J. A. \& Sandler, D. P. Systemic levels of estrogens and PGE2 synthesis in relation to postmenopausal breast cancer risk. Cancer Epidemiol. Biomark. Prev. 26(3), 383-388 (2017).

24. Xiang, F. et al. Metformin inhibits estradiol and prodesterone-induced decidualization of endometrial stromal cells by regulating expression of progesterone receptor, cytokines and matrix metalloproteinases. Biomed. Pharmacother. 109, 1578-1585 (2019).

25. Amalia, A., Abdullah, N. \& Malinta, U. The role of matrix metalloproteinase9 (MMP9) in endometriosis. Indones. J. Obstet. Gynecol. 5(4), 203-207 (2017).

26. Uimari, O. et al. Genome-wide genetic analyses highlight mitogen-activated protein kinase (MAPK) signaling in the pathogenesis of endometriosis. Hum. Reprod. 32, 780-793 (2017).

27. Olea-Flores, M. et al. Extracellular-signal regulated kinase: a central molecule driving epithelial-mesenchymal transition in cancer. Int. J. Mol. Sci. 20(12), 2885 (2019).

28. Seternes, O. M., Kidger, A. M. \& Keyse, S. M. Dual-specificity MAP kinase phosphatases in health and disease. BBA Mol. Cell Res. 1866(1), 124-143 (2019).

29. Ardito, F., Giuliani, M., Perrone, D., Troiano, G. \& Muzio, L. The crucial role of protein phosphorylation in cell signaling and its use as targeted therapy (Review). Int. J. Mol. Med. 40(2), 271-280 (2017).

30. Buscà, R., Pouysségur, J. \& Lenormand, P. ERK1 and ERK2 map kinases: specific roles or functional redundancy?. Front. Cell Dev. Biol. 4, 53 (2016).

31. Li, X., Huang, Y., Jiang, J. \& Frank, S. J. Synergy in ERK activation by cytokine receptors and tyrosine kinase growth factor receptors. Cell Signal 23(12), 417-424 (2011).

32. Lei, Y. Y., Wang, W. J., Mei, J. H. \& Wang, C. L. Mitogen-activated protein kinase signal transduction in solid tumors. Asian Pac. J. Cancer Prev. 15(20), 8539-8548 (2014).

33. Liu, Z., Lisha, Y. I., Miaomiao, D., Guofang, G. \& Yalii, Z. Overexpression of TGF- $\beta$ enhances the migration and invasive ability of ectopic endometrial cells via ERK/MAPK signaling pathway. Exp. Therap. Med. 17, 4457-4464 (2019).

34. Yu, Y. X., Xiu, Y. L. \& Li, Y. L. Transforming growth factor-beta 1 involved in the pathogenesis of endometriosis through regulating expression of vascular endothelial growth factor under hypoxia. Chin. Med. J. 130, 950-956 (2017).

35. Králíčková, M. \& Vetvicka, V. Immunological aspects of endometriosis: a review. Ann. Transl. Med. 3(11), 153 (2015).

36. Symons, L. K. et al. The immunopathophysiology of endometriosis. Trends Mol. Med. 24(9), 748-762 (2018).

37. Carli, C., Metz, C. N., Al-Abed, Y., Naccache, P. H. \& Akoum, A. Up-regulation of cyclooxygenase-2 expression and prostaglandin E2 production in human endometriotic cells by macrophage migration inhibitory factor: involment of novel kinase signaling pathways. Endocrinology 150(7), 3128-3137 (2009).

38. Park, Y. K., Hong, H. \& Jang, B. C. Transcriptional and translational regulation of COX-2 expression by cadmium in C6 glioma cells. Int. J. Mol. Med. 30(4), 960-966 (2012).

39. Olszowski, T. et al. The effect of cadmium on COX-1 and COX-2 gene, protein expression, and enzymatic activity in THP-1 macrophages. Biol. Trace Elem. Res. 165(2), 135-144 (2015).

40. Sugita, R. et al. Simultaneous inhibition of PGE2 and PGI2 signals is necessary to suppress hyperalgesia in rat inflammatory pain models. Mediat. Inflamm. 2016, 9847840 (2016).

41. Ran, Z., Hou, L., Guo, H., Wang, K. \& Li, X. Expression of VEGF, COX-2 and MMP-9 in breast cancer and their relationship with ultrasound findings. Int. J. Clin. Exp. Pathol. 11(9), 4264-4269 (2018).

42. Qi, Q. M., Guo, S. W. \& Liu, X. S. Estrogen biosynthesis and its regulation in endometriosis. Reprod. Dev. Med. 1(1), 55-61 (2017).

43. Lai, T. Y. et al. 17beta-estradiol inhibits prostaglandin E2-induced COX-2 expressions and cell migration by suppressing Akt and ERK1/2 signaling pathways in human LoVo colon cancer cells. Mol. Cell Biochem. 342(1-2), 63-70 (2010).

44. Stacey, W., Bhave, S. \& Uht, R. M. Mechanisms by which $17 \beta$-estradiol (E2) suppress neuronal cox-2 gene expression. PLoS ONE 11(9), e0161430 (2016).

45. Holanda, A. O. et al. Zinc and metalloproteinases 2 and 9: what is their relation with breast cancer?. Rev. Assoc. Med. Bras. 63(1), 78-84 (2017).

46. Bałkowiec, M., Maksym, R. B. \& Włodarski, P. K. The bimodal role of matrix metalloproteinases and their inhibitors in etiology and pathogenesis of endometriosis. Mol. Med. Rep. 18(3), 3123-3136 (2018).

47. Prasad, A. S. Lessons learned from experimental human model of zinc deficiency. J. Immunol. Res. https://doi.org/10.1155/2020/ $9207279(2020)$.

48. Maret, W. Zinc in cellular regulation: the nature and significance of zinc signals. Int. J. Mol. Sci. 18(1), 2285 (2017).

49. Nimmanon, T., Ziliotto, S., Morris, S., Flanagana, L. \& Taylor, K. M. Phosphorylation of zinc channel ZIP7 drives MAPK, PI3K and mTOR growth and proliferation signalling. Metallomics 9(5), 471-481 (2017).

50. Hershfinkel, M. The zinc sensing receptor, ZnR/GPR39, in health and disease. Int. J. Mol. Sci. 19(2), 439 (2018).

51. Kessenbrock, K., Plaks, V. \& Werb, Z. Matrix metalloproteinases: regulators of the tumor microenvironment. Cell 141(1), 52-67 (2010).

52. Giudice, L. Clinical practice: endometriosis. N. Engl. J. Med. 362(25), 2389-2398 (2011).

53. Messalli, E. M. et al. The possible role of zinc in the etiopathogenesis of endometriosis. Clin. Exp. Obstet. Gynecol. 41(5), 541-546 (2014).

54. Hall, S. C. \& Knoell, D. L. Zinc signals in inflammation. in Zinc Signal. 279-304 (2019).

55. Gammoh, N. Z. \& Rink, L. Zinc in infection and inflammation. Nutrients 9(6), 624 (2017).

56. Nosrati, R., Kheirouri, S., Ghodsi, R. \& Ojaghi, H. The effects of zinc treatment on matrix metalloproteinases: a systematic review. J. Trace Elem. Med. Biol. 56, 107-115 (2019).

57. Grzywacz, A. et al. Metal responsive transcription factor 1 (MTF-1) regulates zinc dependent cellular processes at the molecular level. Acta Biochim. Pol. 62(3), 491-498 (2015).

58. Mackeh, R., Marr, A. K., Fadda, A. \& Kino, T. C2H2-type zinc finger proteins: evolutionarily old and new partners of the nuclear hormone receptors. Nucl. Recept. Signal. 15, 1550762918801071 (2018).

59. Jen, J. \& Wang, Y. C. Zinc finger proteins in cancer progression. J. Biomed. Sci. 23, 53 (2016).

60. Cassandri, M. et al. Zinc-finger proteins in health and disease. Cell Death Discov. 3, 17071 (2017).

61. Waller, D. G. \& Sampson, A. P. Nonsteroidal Antiinflammatory Drugs. Medical Pharmacology and Therapeutics 5th edn. (John Wiley \& Sons, 2018). 
62. Luo, S. et al. Niflumic acid exhibits anti-tumor activity in nasopharyngeal carcinoma cells through affecting the expression of ERK1/2 and the activity of MMP2 and MMP9. Int. J. Clin. Exp. Pathol. 8(9), 9990-10001 (2015).

63. Carbone, C., Musumeci, T. \& Pignatello, R. Drug-Biomembrane Interaction Studies: The Application of Calorimetric Techniques (Elsevier, 2013).

64. Srinivas, M., Duffy, H., Delmar, M. \& Spray, D. C. Prospects for pharmacologic targeting of gap junction channels. in Cardiac Electrophysiology 4th ed. From Cell to Bedside 158-167 (2004).

65. McKay, G. A., Reid, J. L. \& Walters, M. R. Lecture Notes: Clinical Pharmacology and Therapeutics (John Wiley and Sons, 2011).

66. Zhang, Z., Chen, F. \& Shang, L. Advances in antitumor effects of NSAIDs. Cancer Manag. Res. 10, 4631-4640 (2018).

67. Bank, A., Yu, J. \& Zhang, L. NSAIDs downregulate Bcl-X(L) and dissociate BAX and Bcl-X(L) to induce apoptosis in colon cancer cells. Nutr. Cancer 60(1), 98-103 (2008).

68. Liggett, J. L., Zhang, X., Eling, T. E. \& Baek, S. J. Anti-tumor activity of non-steroidal anti-inflammatory drugs: cyclooxygenaseindependent targets. Cancer Lett. 346(2), 217-224 (2014).

69. Kucherenko, Y. V. \& Lang, F. Niflumic acid affects store-operated $\mathrm{Ca}(2+)$-permeable (SOC) and $\mathrm{Ca}(2+)$-dependent $\mathrm{K}(+)$ and $\mathrm{Cl}$ (-) ion channels and induces apoptosis in K562 cells. J. Membr. Biol. 247(7), 627-638 (2014).

70. Vanden-Daele, L., Baydens, C. \& Van de Voorde, J. Characterization of the retina-induced relaxation in mice. Graefe Arch. Clin. Exp. Ophtalmol. 256, 1905-1912 (2018).

71. Lin, X. et al. Flufenamic acid inhibits adipogenic differentiation of messenchymal stem cells by antagonizing the PI3K/AKT pathway. Stem Cells Int. 2020, 1-12 (2020).

72. Zhang, S. et al. Flufenamic acid inhibits osteoclast formation and bone resorption and act against estrogen-dependent bone loss in mice. Int. Immunopharmacol. 78, 106014 (2020).

73. Lang, R. J. \& Hashitani, H. Role of prostatic interstitial cells in prostate motility. J. Smooth Muscle Res. 53, 57-72 (2017).

74. Choi, H. et al. COX-2 expression mediated by calcium-TonEBP signaling axis under hyperosmotic conditions serves osmoprotective function in nucleus pulposus cells. J. Biol. Chem. 293(23), 8969-8981 (2018).

75. Kuramoto, H. \& Nishida, M. Cell and Molecular Biology of Endometrial Carcinoma (Springer, 2012).

76. Orlando, B. J. \& Malkowski, M. G. Substrate-selective inhibition of cyclooxygeanse-2 by fenamic acid derivatives is dependent on peroxide tone. J. Biol. Chem. 291, 15069-15081 (2016).

77. Arshad, M., Conzelmann, C., Assad Riaz, M., Noll, T. \& Gunduz, D. Inhibition ox Cx3 attenuated ERK1/2 activation, enhances the expression of Cav-1 and supress cell proliferation. Int. J. Mol. Med. 42(5), 2811-2818 (2018).

78. Glab, J. A. et al. DR5 and caspase-8 are dispensable in ER stress-induced apoptosis. Cell Death Differ. 24(5), 944-950 (2017).

79. Smolko, L. et al. Zinc(II) niflumato complex with neocuproine: synthesis, crystal structure, characterization and cytotoxic effects on human endometrial cell lines. J. Mol. Struct. 1237, 130312 (2021).

80. Leung, C. H. et al. Metal complexes as inhibitors of transcription factor activity. Coord. Chem. Rev. 257(21-22), 3139-3151 (2013).

81. Takahashi, Y. et al. Protective role of matrix metalloproteinase-2 in allergic bronchial asthma. Front. Immunol. 10, 1795 (2019).

82. Stefanowicz-Hajduk, K. \& Ochocka, J. R. Real-time cell analysis system in cytotoxicity applications: usefulness and comparison with tetrazolium salt assays. Toxicol. Rep. 7, 335-344 (2020).

\title{
Acknowledgements
}

The work was financially supported by the Grants VEGA 1/0620/19 and VEGA 1/083/18. We thank to prof. Starzinski-Powitz, Dr. Jana Stofilova, PhD., and Dr. Zuzana Gulasova, PhD for professional help and cooperation.

\section{Author contributions}

M.R.: conceptualization, project administration, writing: review and editing, supervision. I.Š.: conceptualization, investigation, writing: review and editing. Z.K.: data curation, validation, writing: original draft. L.S.: investigation, writing: review and editing. M.A.: validation. P.U.: funding acquisition. M.M.: supervision.

\section{Competing interests}

The authors declare no competing interests.

\section{Additional information}

Supplementary Information The online version contains supplementary material available at https://doi.org/ 10.1038/s41598-021-98512-9.

Correspondence and requests for materials should be addressed to I.. .

Reprints and permissions information is available at www.nature.com/reprints.

Publisher's note Springer Nature remains neutral with regard to jurisdictional claims in published maps and institutional affiliations.

\begin{abstract}
Open Access This article is licensed under a Creative Commons Attribution 4.0 International License, which permits use, sharing, adaptation, distribution and reproduction in any medium or format, as long as you give appropriate credit to the original author(s) and the source, provide a link to the Creative Commons licence, and indicate if changes were made. The images or other third party material in this article are included in the article's Creative Commons licence, unless indicated otherwise in a credit line to the material. If material is not included in the article's Creative Commons licence and your intended use is not permitted by statutory regulation or exceeds the permitted use, you will need to obtain permission directly from the copyright holder. To view a copy of this licence, visit http://creativecommons.org/licenses/by/4.0/.
\end{abstract}

(C) The Author(s) 2021 